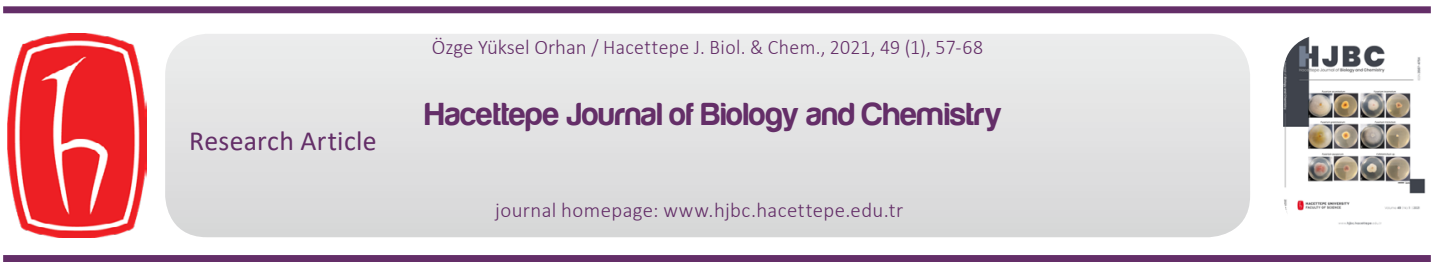

\title{
Investigation of Biocatalytic Absorption and Ultrasound-Assisted Desorption Performance of $\mathrm{CO}_{2}$ Capture
}

\section{$\mathrm{CO}_{2}$ Yakalamanın Biyokatalitik Absorpsiyon ve Ultrasonik-Destekli Desorpsiyon Performansının Incelenmesi}

\author{
Özge Yüksel Orhan \\ Hacettepe University, Department of Chemical Engineering, Ankara, Turkey.
}

\section{ABSTRACT}

\begin{abstract}
The $\mathrm{CO}_{2}$ absorption-desorption performance of non-aqueous solutions comprising a sterically hindered amine system (2-amino-2-ethyl-1,3-propanediol (AEPD): 1-hexanol) was investigated in a gas-liquid stirred cell reactor under sequential absorption-desorption cycles. The absorption capacity and initial absorption rate were calculated for different concentrations of AEPD: 1-hexanol at $303 \mathrm{~K}$ and 2 bar absolute pressure. Increasing the amount of AEPD increased the $\mathrm{CO}_{2}$ absorption capacity. The biocatalytic effect of a constant amount of carbonic anhydrase (CA) on the $\mathrm{CO}_{2}$ absorption performance was also investigated, and the CA enzyme was found to increase the total amount of absorbed $\mathrm{CO}_{2}$. $\mathrm{The}^{\mathrm{CO}_{2}}$ loading of AEPD: 1-hexanol and CA activated AEPD: 1-hexanol were 0.88 and $0.97 \mathrm{~mol} \mathrm{CO} / \mathrm{mol}$ AEPD, respectively. $\mathrm{CO}_{2}$ desorption experiments were performed in different sequences of the same experimental set-up at $363 \mathrm{~K}$ and 1.1 bar absolute $\mathrm{N}_{2}$ pressure. The effect of ultrasonic irradiation on the desorption performance of $0.1 \mathrm{~g} / \mathrm{L}$ CA catalyzed AEPD: 1-hexanol system was also investigated. It was observed that ultrasonic assistance shortened the desorption time and enhanced the desorption rate. Furthermore, the effectiveness of regeneration, the reusability, and performance loss of AEPD: 1-hexanol, in the presence and absence of CA, were analyzed by Fourier transform infrared spectrometry.
\end{abstract}

\section{Key Words}

$\mathrm{CO}_{2}$ capture, carbonic anhydrase, FTIR, sterically hindered amine.

\section{öz}

Sterik engelli amin sisteminin susuz çözeltisinin (2-amino-2-etil-1,3-propandiol (AEPD): 1-hekzanol) ardışık $\mathrm{CO}_{2}$ Sabsorpsiyon-desorpsiyon performansı gaz-sıvı karıştırmalı hücre reaktöründe incelenmiştir. Farklı AEPD: 1-hekzanol konsantrasyonları için absorpsiyon kapasitesi ve başlangıç absorpsiyon hızı $303 \mathrm{~K}$ ve 2 bar mutlak basınçta hesaplanmıştır. AEPD miktarının artırıması $\mathrm{CO}_{2}$ absorpsiyon kapasitesini arttırmıştır. Sabit miktarda karbonik anhidrazın (CA) $\mathrm{CO} 2$ absorpsiyon performansı üzerindeki biyokatalitik etkisi de araştırılmış, ve CA enziminin toplam absorplanan $\mathrm{CO}_{2}$ miktarını arttırdığı bulunmuştur. AEPD: 1-hekzanol ve CA ile aktifleştirilen AEPD: 1-hekzanolün $\mathrm{CO}_{2}$ yüklemesi sırasıyla 0.88 ve 0.97 mol $\mathrm{CO}_{2} / \mathrm{mol}$ AEPD bulunmuştur. $\mathrm{CO}_{2}$ desorpsiyon deneyleri, $363 \mathrm{~K}$ ve 1.1 bar mutlak $\mathrm{N}_{2}$ basıncında aynı deney düzeneğinin farklı diziliminde gerçekleştirilmiştir. Ultrasonik ışınlamanın $0.1 \mathrm{~g} / \mathrm{L}$ CA katalizli AEPD: 1-hekzanol sisteminin desorpsiyon performansı üzerindeki etkisi de araştırılmıştır. Ultrasonik desteğin desorpsiyon süresini kısalttığı ve desorpsiyon hızını arttırdığı gözlenmiştir. Ayrıca, AEPD:1-Hekzanol sisteminin, CA yokluğunda ve varlığındaki, rejenerasyonun etkinliği, yeniden kullanılabilirliği ve performans kaybı Fourier dönüşümü kızılötesi spektrometresi ile analiz edilmiştir.

\section{Anahtar Kelimeler}

$\mathrm{CO}_{2}$ yakalama, karbonik anhidraz, FTIR, sterik engelli amin.

Article History: Received: Aug 19, 2020; Revised: Oct 12, 2020; Accepted: Oct 12, 2020; Available Online: Nov 20, 2020.

Dol: https://doi.org/10.15671/hjbc.776359

Correspondence to: O. Yuksel Orhan, Department of Chemical Engineering, Hacettepe University, Ankara, Turkey.

E-Mail: oyuksel@hacettepe.edu.tr 


\section{INTRODUCTION}

$T_{\text {hem }}^{\text {he }}$ he emission of carbon dioxide $\left(\mathrm{CO}_{2}\right)$, one of the primary greenhouse gases (GHGs) responsible for global warming, is increasing. $\mathrm{CO}_{2}$ absorbs less heat per molecule than do other greenhouse gases such as methane $\left(\mathrm{CH}_{4}\right)$ or nitrous oxide $\left(\mathrm{N}_{2} \mathrm{O}\right)$. However, $\mathrm{CO}_{2}$ is more abundant and stays much longer in the atmosphere [1]. Atmospheric $\mathrm{CO}_{2}$ concentrations have reached an alarming level of around $410 \mathrm{ppm}$ in 2019, according to the International Energy Agency report [2]. Anthropogenic $\mathrm{CO}_{2}$ emissions mainly result from the transportation and burning of fossil fuels for energy [3], while electricity generation and the power sector are responsible for the lion's share of non-anthropogenic $\mathrm{CO}_{2}$ emissions [4]. Therefore, reduction of $\mathrm{CO}_{2}$ emissions is an important topic on the global agenda to fight climate change.

The absorption-desorption process using aqueous amine solvents has been demonstrated as widely-used methodology for post-combustion $\mathrm{CO}_{2}$ capture (PCC) [5]. Aqueous $30 \mathrm{wt} \%$ monoethanolamine (MEA) is considered a benchmark solution for $\mathrm{CO}_{2}$ separation from bulk $\mathrm{CO}_{2}$ gas streams. Even though aqueous aminebased absorbents have good $\mathrm{CO}_{2}$ absorption characteristics, a large amount of energy is required during regeneration. The regeneration heat for aqueous $30 \mathrm{wt} \%$ MEA is around $4 \mathrm{GJ} /$ ton $\mathrm{CO}_{2}[6,7]$. Solvent regeneration is energetically demanding, representing about $70 \%$ to $80 \%$ of the total energy consumption [8]. The high specific heat of water increases the sensible heat, and the low boiling point of water results in vaporization during the regeneration process, leading to solvent loss [9]. This high energy demand is the driving force behind the development of new solvents with lower regeneration energy consumption. In recent years, there have been several proposals for using water-lean or non-aqueous amine solutions due to their energy-saving potential, but there is still a significant gap from the desired level [7, 10-16]. The widely known organic solvent, 1-hexanol, has a high boiling point but lower heat capacity and vaporization enthalpy than those of water. In the present study, 1-hexanol is proposed as a non-aqueous medium for cyclic $\mathrm{CO}_{2}$ absorption and desorption.

MEA, a widely known primary amine, shows higher reactivity with $\mathrm{CO}_{2}$, has low viscosity, and is inexpensive and easily available; however, its corrosive and volatile nature, as well as low $\mathrm{CO}_{2}$ loading $\left(\mathrm{mol} \mathrm{CO}_{2} / \mathrm{mol} \mathrm{MEA}=\right.$
$0.5)$, have necessitated the search for more efficient absorbents [17]. Primary and secondary amines commonly react with $\mathrm{CO}_{2}$ to form stable carbamate anions, while tertiary amines form bicarbonate ions [18]. Tertiary amines are known to have higher $\mathrm{CO}_{2}$ loading capacity $(\mathrm{mol} \mathrm{CO} / \mathrm{mol}$ amine $\approx 1.0$ ) but lower thermal stability and low kinetics. In this context, sterically hindered amines (SHAs) have been suggested as a viable alternative to primary, secondary, and tertiary amines as efficient absorbents for carbon capture. SHAs have a functional group located close to the amino group. The resulting steric hindrance produces weaker C-N bonds upon reaction with $\mathrm{CO}_{2}$, because of which lower energy is required for solvent regeneration [19]. SHAs have been strongly recommended as potential absorbents due to their high theoretical loading capacity of up to $1.0 \mathrm{~mol} \mathrm{CO} / \mathrm{mol}$ amine [20]. Although SHAs show lower reaction kinetics than do primary and secondary amines, they show faster reaction kinetics than do tertiary amines [21]. 2-Amino-2-methyl-1-propanol (AMP), which is the sterically hindered form of MEA, has been intensively studied [14, 22-26]. The findings led to the introduction of cost-effective and easily regenerable nonaqueous $\mathrm{CO}_{2}$ absorbents, based on the sterically hindered primary amine, 2-amino-2-ethyl-1,3-propanediol (AEPD), i.e. AEPD: 1-hexanol solution. AEPD is a potentially useful sterically hindered amine that forms an unstable carbamate upon reaction with $\mathrm{CO}_{2}$.

Piperazine (PZ) and its derivatives are commonly used promoters to enhance the $\mathrm{CO}_{2}$ kinetics and absorption capacity [27-30]. This study proposes the use of biocatalysts to promote the $\mathrm{CO}_{2}$ absorption-desorption process. The ubiquitous occurrence of carbonic anhydrase (CA) enzyme in nature and its kinetic potential make it a good biocatalyst for the reversible reactions between $\mathrm{CO}_{2}$ and amines. CA from bovine erythrocytes is a widely reported biocatalyst for the $\mathrm{CO}_{2}$ hydration process. Although there have been many studies on the biocatalytic effect of $\mathrm{CA}$ on $\mathrm{CO}_{2}$ absorption kinetics, the effect of $\mathrm{CO}_{2}$ loading in gas-liquid reactors has not been examined yet [31-36]

A novel solvent regeneration technique, called the ultrasound-assisted method, was also used to enhance the desorption performance and further reduce the energy consumption. Bubbles produced during the ultrasonic irradiation generated shockwaves, which increased the interfacial area between the gas and the liquid, resulting in enhanced mass transfer [37-40]. This triggered 
the degassing action, leading to more efficient removal of $\mathrm{CO}_{2}$ from the loaded solution. The superior performance of this ultrasound-assisted technique makes it a potentially attractive alternative to the traditional desorption process. The knowledge obtained contributed to the literature, as well as formed the basis for the development of a new generation of more efficient $\mathrm{CO}_{2}$ capture technologies [39]. This new understanding will help the industry achieve significant savings in terms of both capital and operating costs of $\mathrm{CO}_{2}$ capture and separation processes, which can significantly reduce the greenhouse gas effects and benefit the environment.

\section{MATERIALS and METHODS}

\section{Gas-liquid stirred cell contact reactor}

Gas absorption and desorption experiments were performed in a gas-liquid stirred cell reactor (model RDCSTR 200, Sinerji, Turkey). The experimental set-up consisted of a stainless-steel reactor with a heating jacket, a PID-controlled power control unit, and a data acquisition system (Figure 1). The other important compo- nents of the reactor system are a mass flow controller (MFC) and a mass flow meter (MFM). The stainless-steel reactor has a driver motor capable of a stirring rate of 50-500 rpm, along with digital temperature and pressure sensors connected to a data acquisition system. The system can operate under a wide range of temperature and pressure conditions, 293-373 K and 0-10 bar, respectively.

In this study, the $\mathrm{CO}_{2}$ absorption performance of AEPD: 1-hexanol, in the presence and absence of CA, was investigated with the help of high-precision flowmeters connected to the stirred reactor. The effect of amine concentrations, and the presence of CA enzyme on $\mathrm{CO}_{2}$ absorption capacity were discussed. During an experimental run, the inlet and outlet flow rates of $\mathrm{CO}_{2}$ were measured by the MFM and MFC and recorded at $10 \mathrm{~s}$ intervals until the MFM values approached the set MFC values. The difference between the inlet and outlet gas streams corresponded to the amount of $\mathrm{CO}_{2}$ absorbed. The total amount of $\mathrm{CO}_{2}$ captured by the solvent was calculated by the numerical integration method. This cal-

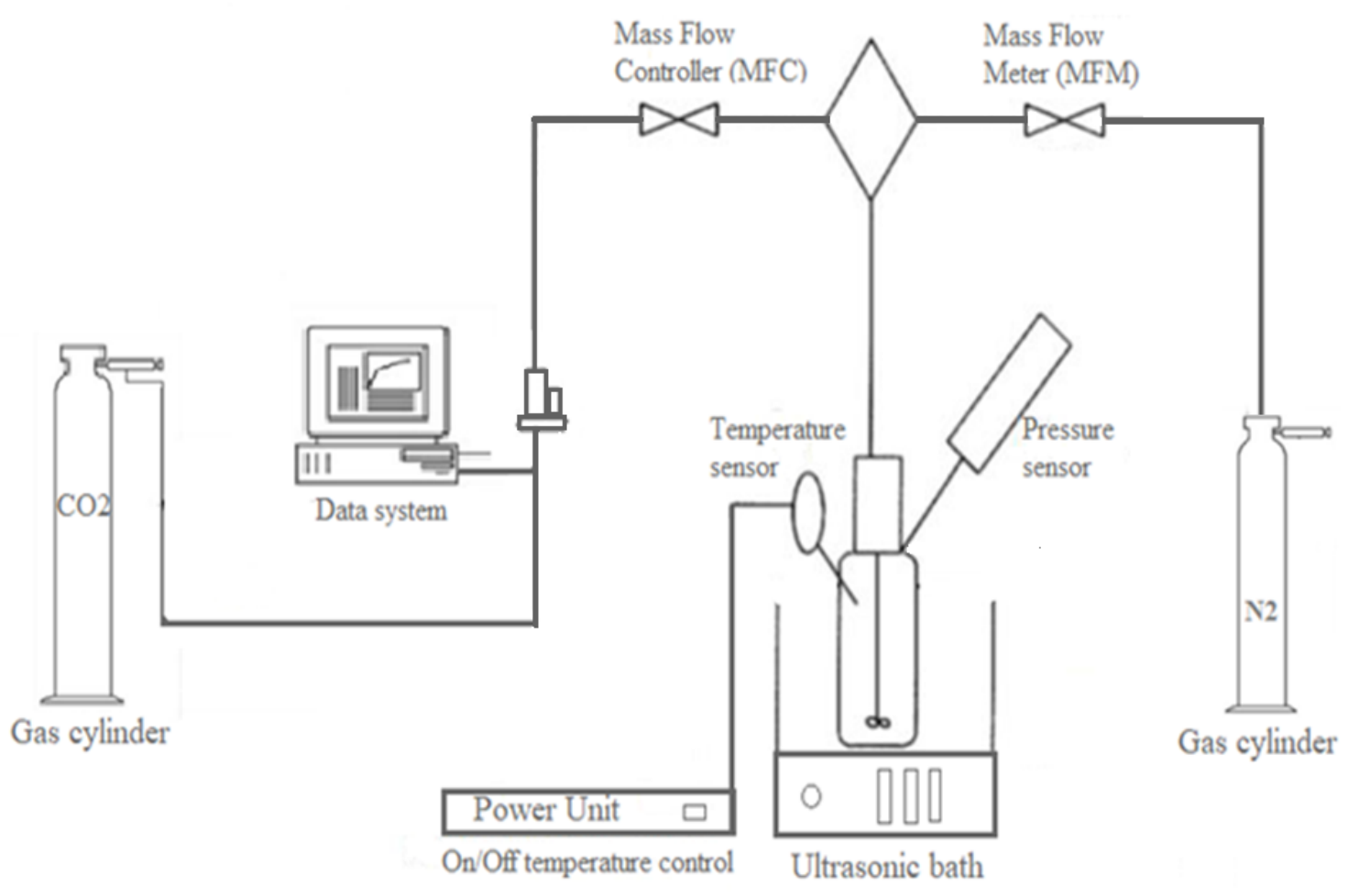

Figure 1.Systematic view of experimental set-up of gas- liquid contact reactor 
culated cumulative volumetric amount was converted to absorbed $\mathrm{CO}_{2}$ in moles by applying the necessary unit changes. The initial absorption rates ( $\mathrm{mol} / \mathrm{s})$ were calculated from the slopes of the initial and the linear region of the $\mathrm{CO}_{2}$ loading plot, as shown in Figure 2. Then, this loading rate was divided by the cross-sectional area of the reactor to obtain the general expression for the initial absorption rate $\left(\mathrm{mol} / \mathrm{m}^{2}\right.$.s). The convenience of the initial absorption rates for a fast reaction was investigated according to the first-order reaction rate equation proposed by Danckwerts [41]. This equation provides solubility, diffusivity and reaction rate in the combined form, $A /\left(D_{A} k o\right)^{0.5}$. To satisfy pseudo first-order conditions, a gas-liquid contact reactor must operate at high concentration ranges of reactants. Opportunely, this concentration range matches to industrial conditions well. It should be noted that, the reaction of $\mathrm{CO}_{2}$ is actually reversible. However, as in our case, if we take into account only the initial gas absorption (i.e. fresh solvent), the back pressure of dissolved $\mathrm{CO}_{2}$ will be negligible and Equation 1 will be applicable.

$$
\overline{\mathrm{R}}=\mathrm{A}^{*} \sqrt{D_{A} k_{o}}
$$

Where, $\overline{\mathrm{R}}$ is the measured $\mathrm{CO}_{2}$ absorption rate (mol/ $\left.\mathrm{m}^{2} \mathrm{~s}\right), \mathrm{A}^{*}$ is solubility of dissolved $\mathrm{CO}_{2}$ at the gas-liquid interface $\left(\mathrm{mol} / \mathrm{m}^{3}\right), \mathrm{D}_{\mathrm{A}}$ is the molecular diffusivity of dissolved $\mathrm{CO}_{2}\left(\mathrm{~m}^{2} / \mathrm{s}\right)$ and $\mathrm{k}_{\mathrm{o}}$ is the pseudo-first order reaction rate constant $\left(\mathrm{s}^{-1}\right)$.

In the absorption experiments, the stirred reactor tank pressure was maintained at 2 bar absolute $\mathrm{CO}_{2}$ pressure, the temperature was maintained at $303 \mathrm{~K}$, and the MFC was set to $10 \mathrm{sccm}$. Since the absorption process occurs at constant pressure, there was a continuous $\mathrm{CO}_{2}$ input into the system, equivalent to the amount of $\mathrm{CO}_{2} \mathrm{ab}$ sorbed by the reactive solution. The change in the flow rates measured by the MFM and MFC during a typical experimental run, and the $\mathrm{CO}_{2}$ loading as a function of time are plotted as shown in Figure 2.

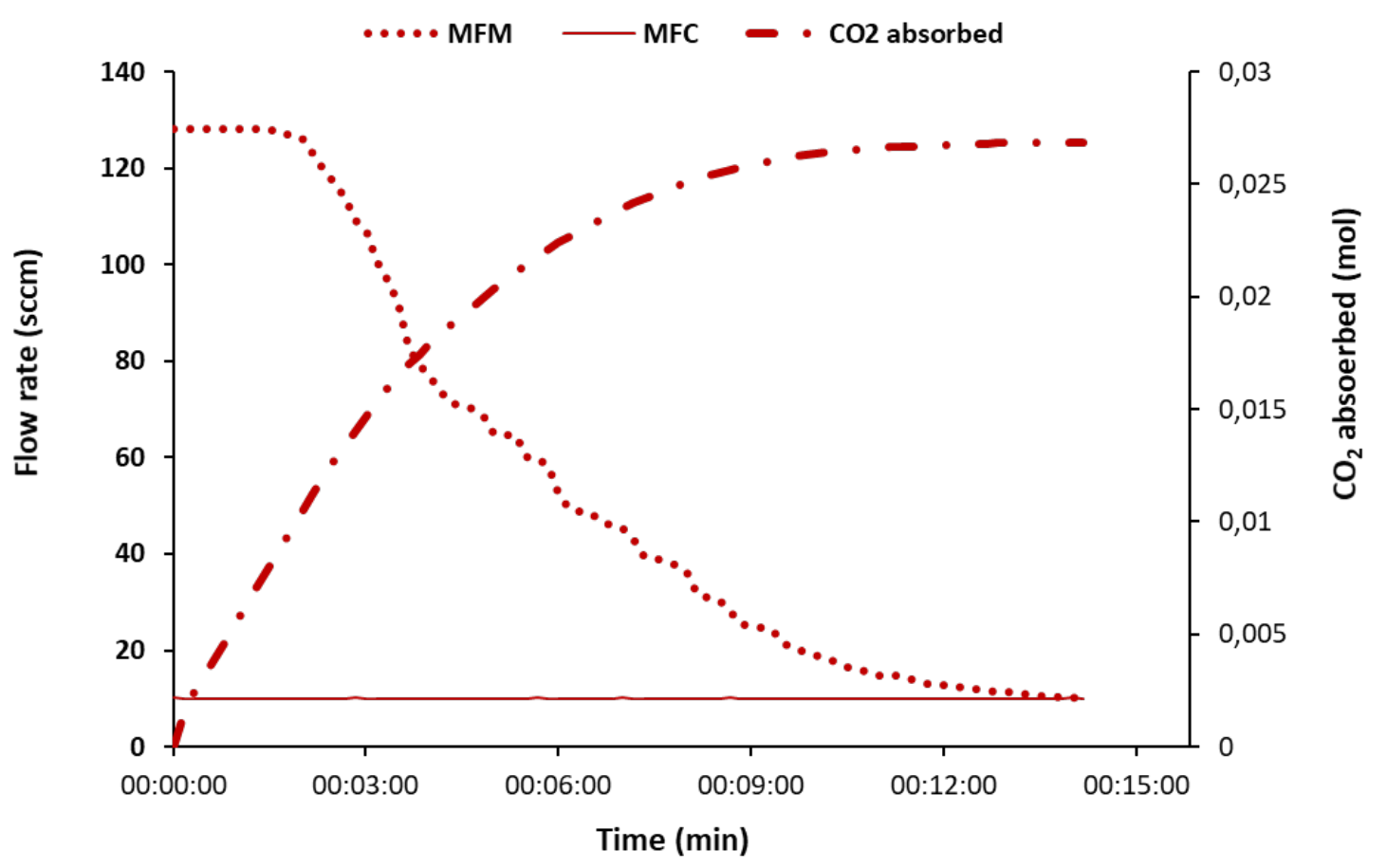

Figure 2. Typical absorption graph of $1.0 \mathrm{M}$ AEPD: 1-hexanol at $303 \mathrm{~K}$ and 2 bar. 
It was noticed that the absorption rate of the fresh AEPD:1-hexanol solution decreases over time as the solution is saturated with $\mathrm{CO}_{2}$. The area between the MFC and MFM curves gives the amount of $\mathrm{CO}_{2}$ absorbed throughout an experimental run. Toward the end of the experiment, the flow value observed in the MFM approached the value of the previously determined MFC and reached equilibrium. Equalization of the MFM and MFC values meant that the solution would not be able to capture any more $\mathrm{CO}_{2}$.

In addition, different sequences of the same experimental set-up were used to test the reusability of the solutions and to examine the desorption performance. In the desorption experiments, $\mathrm{CO}_{2}$ was removed from the loaded solution by simple heating and sweeping with an inert gas such as nitrogen $\left(\mathrm{N}_{2}\right) . \mathrm{CO}_{2}$ desorption experiments on AEPD:1-hexanol systems, for different concentrations, were performed at $363 \mathrm{~K}$ and 1.1 bar absolute $\mathrm{N}_{2}$ pressure. Ultrasound-assisted desorption experiments were performed in a Bandelin, DL $514 \mathrm{BH}$ model ultrasonic bath with a constant wave frequency of $37 \mathrm{kHz}$, at $333 \mathrm{~K}$ and 1.1 bar absolute $\mathrm{N}_{2}$ pressure.

In order to investigate the reversibility and performance losses of the SHA solutions, the consecutive absorption-desorption experiments were repeated for 3 cycles. In addition, Fourier infrared transform (FTIR) spectroscopy analyses were performed to demonstrate the regeneration effectiveness and the cyclic perfor- mance of $\mathrm{CO}_{2}$-rich and $\mathrm{CO}_{2}$-lean $\mathrm{SHA}$ solutions in the presence and absence of CA. An FTIR analyzer (Thermo Scientific- NICOLET 6700) was used for detecting the functional groups and characterizing the chemical bonds. Further details of the gas-liquid contact reactor and experimental procedure can be found in the literature $[12,42,43]$.

\section{RESULTS and DISCUSSION}

\section{Absorption-desorption performance}

Gas absorption experiments on the $30 \mathrm{~mL}$ AEPD: 1-hexanol system in the presence and absence of CA were performed at $303 \mathrm{~K}$ and 2 bar $\mathrm{CO}_{2}$ absolute pressure in a gas-liquid contact reactor. The AEPD: 1-hexanol system was exposed to at least 3 capture and release cycles in order to investigate its reusability and cyclic capacity. Each experimental set was repeated 3 times and the average of 3 replicate experiments were represented. The absorption capacity and initial absorption rate of the consecutive absorption-desorption experiments for the $0.5 \mathrm{M}$ AEPD: 1-hexanol system are summarized in Table 1 . The highest $\mathrm{CO}_{2}$ loading capacity was reached in the first absorption cycle whereupon a slight decrease was observed in subsequent cycles (Table 1). The absorption capacity loss of the AEPD: 1-hexanol system after the third regeneration cycle was found to be $25 \%$. This can be referred to the incomplete removal of $\mathrm{CO}_{2}$ during desorption cycle, which was carried out at $363 \mathrm{~K}$ and 1.1 bar absolute pressure.

Table 1. Cyclic absorption capacities and initial absorption rate of 0.5 M AEPD: 1-hexanol.

\begin{tabular}{ccc}
\hline 0.5 M AEPD: 1-hexanol: CA & $\begin{array}{c}\text { Absorption capacity } \\
(\mathrm{mol})\end{array}$ & $\begin{array}{c}\text { Initial absorption rate } \\
\left(\mathrm{kmol}^{2} \mathrm{~m}^{2} . \mathrm{s}\right) \times\left(10^{5}\right)\end{array}$ \\
\hline $1^{\text {st }}$ Absorption & 0.0126 & 1.84 \\
\hline $2^{\text {nd }}$ Absorption & 0.0104 & 1.29 \\
\hline $3^{\text {rd }}$ Absorption & 0.0091 & 1.14 \\
\hline
\end{tabular}

Table 2. Cyclic absorption capacities and initial absorption rate of 0.75 M AEPD: 1-hexanol.

\begin{tabular}{ccc}
0.75 M AEPD: 1-hexanol & $\begin{array}{c}\text { Absorption capacity } \\
(\mathrm{mol})\end{array}$ & $\begin{array}{c}\text { Initial absorption rate } \\
\left(\mathrm{kmol} / \mathrm{m}^{2} . \mathrm{s}\right) \times\left(10^{5}\right)\end{array}$ \\
\hline $1^{\text {st }}$ Absorption & 0.0197 & 1.59 \\
\hline $2^{\text {nd }}$ Absorption & 0.0178 & 1.47 \\
\hline $3^{\text {rd }}$ Absorption & 0.0149 & 1.31 \\
\hline
\end{tabular}


62 Özge Yüksel Orhan / Hacettepe J. Biol. \& Chem., 2021, 49 (1), 57-68

Table 3. Cyclic absorption capacities and initial absorption rate of 1.0 M AEPD: 1-hexanol.

\begin{tabular}{ccc}
\hline 1.0 M AEPD: 1-hexanol & $\begin{array}{c}\text { Absorption capacity } \\
(\mathrm{mol})\end{array}$ & $\begin{array}{c}\text { Initial absorption rate } \\
\left(\mathrm{kmol} / \mathrm{m}^{2} . \mathrm{s}\right) \times\left(10^{5}\right)\end{array}$ \\
\hline $1^{\text {st }}$ Absorption & 0.0267 & 2.27 \\
\hline $2^{\text {nd }}$ Absorption & 0.0241 & 1.98 \\
\hline $3^{\text {rd }}$ Absorption & 0.0206 & 1.63 \\
\hline
\end{tabular}

Furthermore, a reduction in the initial absorption rate was observed with a decrease in the absorption capacity. The absorption capacity and initial absorption rate of 0.75 M AEPD: 1-hexanol and 1.0 M AEPD: 1-hexanol systems are reported in Tables 2 and 3, respectively.

As expected, the absorption capacity increased with increasing concentrations of the SHA, as shown in Tables 2 and 3. However, no such analogy was observed for the initial absorption rates.

$\mathrm{CO}_{2}$ absorption experiments of the CA-activated AEPD: 1-hexanol system were performed at $303 \mathrm{~K}$ and 2 bar absolute pressure. The absorption capacity and initial absorption rate for different concentrations of the CA-catalyzed AEPD: 1-hexanol system are presented in Tables 4-6. The amount of CA enzyme added to various concentrations of the AEPD: 1-hexanol system was set at $0.1 \mathrm{~g} / \mathrm{L}$. Desorption experiments were performed at $333 \mathrm{~K}$ to avoid the denaturation of the CA enzyme. As is evident from Tables 4-6, the highest $\mathrm{CO}_{2}$ loading capacity was observed in the first absorption, after which a slight decrease was observed in the subsequent absorption cycles. The absorption capacity loss of the CAactivated AEPD: 1-hexanol systems after the third regeneration cycle was found to be $15 \%$.

Both the $\mathrm{CO}_{2}$ absorption capacity and the initial absorption rate of the CA-catalyzed AEPD: 1-hexanol system were higher than those of the uncatalyzed system. In order to calculate the actual stoichiometry of the reaction between $\mathrm{CO}_{2}$ and the AEPD: 1-hexanol systems, the first $\mathrm{CO}_{2}$ absorption capacity was plotted against the corresponding amount of AEPD (Figure 3).

Table 4. Cyclic absorption capacities and initial absorption rate of $0.5 \mathrm{M}$ AEPD: 1-hexanol system catalysed by $0.1 \mathrm{~g} / \mathrm{L}$ CA.

\begin{tabular}{ccc}
\hline 0.5 M AEPD: 1-hexanol: CA & $\begin{array}{c}\text { Absorption capacity } \\
(\mathrm{mol})\end{array}$ & $\begin{array}{c}\text { Initial absorption rate } \\
\left(\mathrm{kmol} / \mathrm{m}^{2} . \mathrm{s}\right) \times\left(10^{5}\right)\end{array}$ \\
\hline $1^{\text {st }}$ Absorption & 0.0144 & 2.36 \\
\hline $2^{\text {nd }}$ Absorption & 0.0132 & 2.21 \\
\hline $3^{\text {rd }}$ Absorption & 0.0121 & 1.85 \\
\hline
\end{tabular}

Table 5. Cyclic absorption capacities and initial absorption rate of 0.75 M AEPD: 1-hexanol system catalysed by $0.1 \mathrm{~g} / \mathrm{L}$ CA.

\begin{tabular}{ccc}
\hline 0.75 M AEPD: 1-hexanol: CA & $\begin{array}{c}\text { Absorption capacity } \\
(\mathrm{mol})\end{array}$ & $\begin{array}{c}\text { Initial absorption rate } \\
\left(\mathrm{kmol}^{2} \mathrm{~m}^{2} . \mathrm{s}\right) \times\left(10^{5}\right)\end{array}$ \\
\hline $1^{\text {st }}$ Absorption & 0.0219 & 2.41 \\
\hline $2^{\text {nd }}$ Absorption & 0.0208 & 2.25 \\
\hline $3^{\text {rd }}$ Absorption & 0.0189 & 2.18 \\
\hline
\end{tabular}

Table 6. Cyclic absorption capacities and initial absorption rate of 1.0 M AEPD: 1-hexanol system catalysed by $0.1 \mathrm{~g} / \mathrm{L}$ CA.

\begin{tabular}{ccc}
\hline $1.0 \mathrm{M}$ AEPD: 1-hexanol: CA & $\begin{array}{c}\text { Absorption capacity } \\
(\mathrm{mol})\end{array}$ & $\begin{array}{c}\text { Initial absorption rate } \\
\left(\mathrm{kmol} / \mathrm{m}^{2} . \mathrm{s}\right) \times\left(10^{5}\right)\end{array}$ \\
\hline $1^{\text {st }}$ Absorption & 0.0289 & 2.54 \\
\hline $2^{\text {nd }}$ Absorption & 0.0263 & 2.37 \\
\hline $3^{\text {rd }}$ Absorption & 0.0247 & 2.21 \\
\hline
\end{tabular}




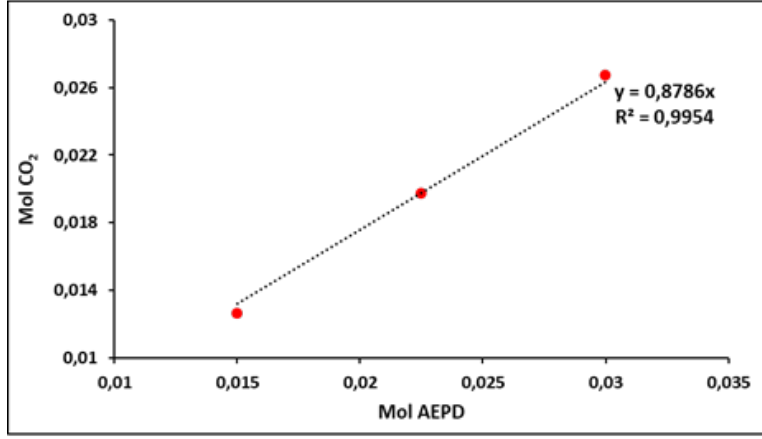

(a)

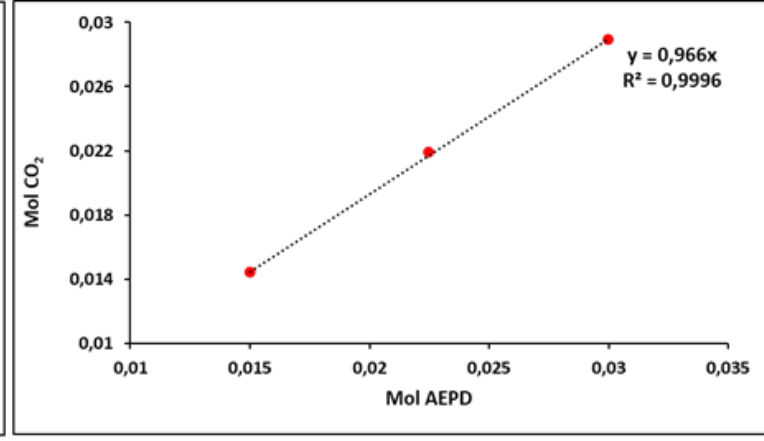

(b)

Figure 3. $\mathrm{CO}_{2}$ loading graphs of (a) AEPD: 1-hexanol system (b) AEPD: 1-hexanol system catalysed by $0.1 \mathrm{~g} / \mathrm{L} C A$ at $303 \mathrm{~K}$.

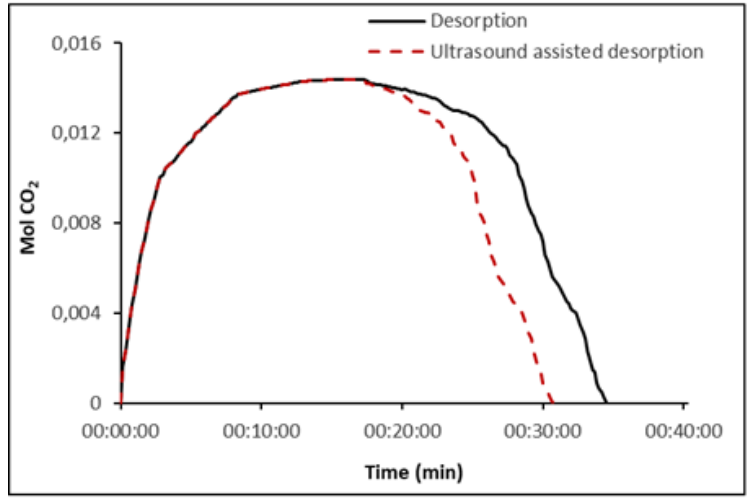

(a)

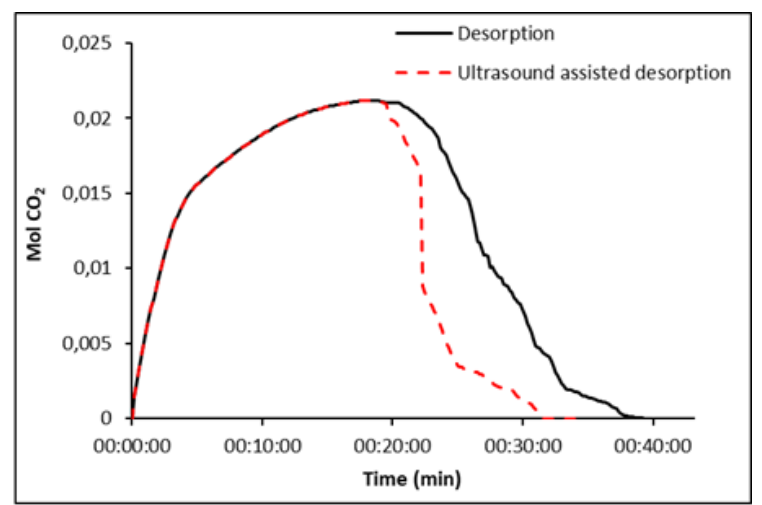

(b)

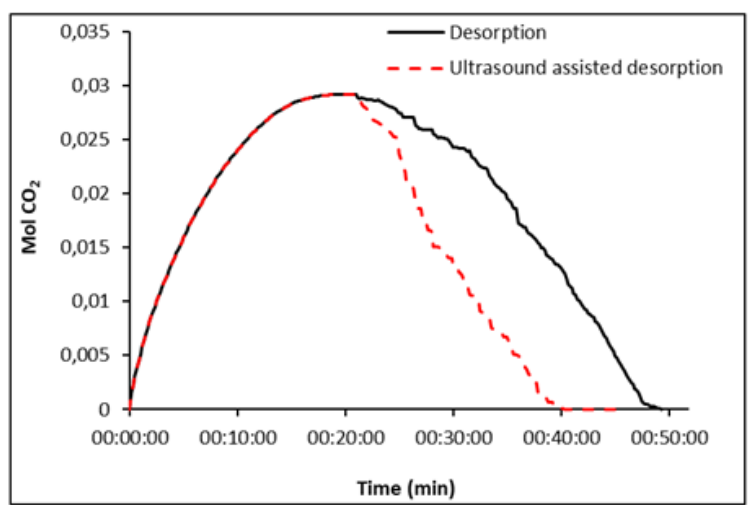

(c)

Figure 4. Ultrasound-assisted desorption performances for (a) 0.5 M AEPD: 1-hexanol system catalysed by 0.1 g/L CA (b) 0.75 M AEPD: 1-hexanol system catalysed by $0.1 \mathrm{~g} / \mathrm{L}$ CA (c) $1.0 \mathrm{M}$ AEPD: 1 -hexanol system catalysed by $0.1 \mathrm{~g} / \mathrm{L} \mathrm{CA}$. 


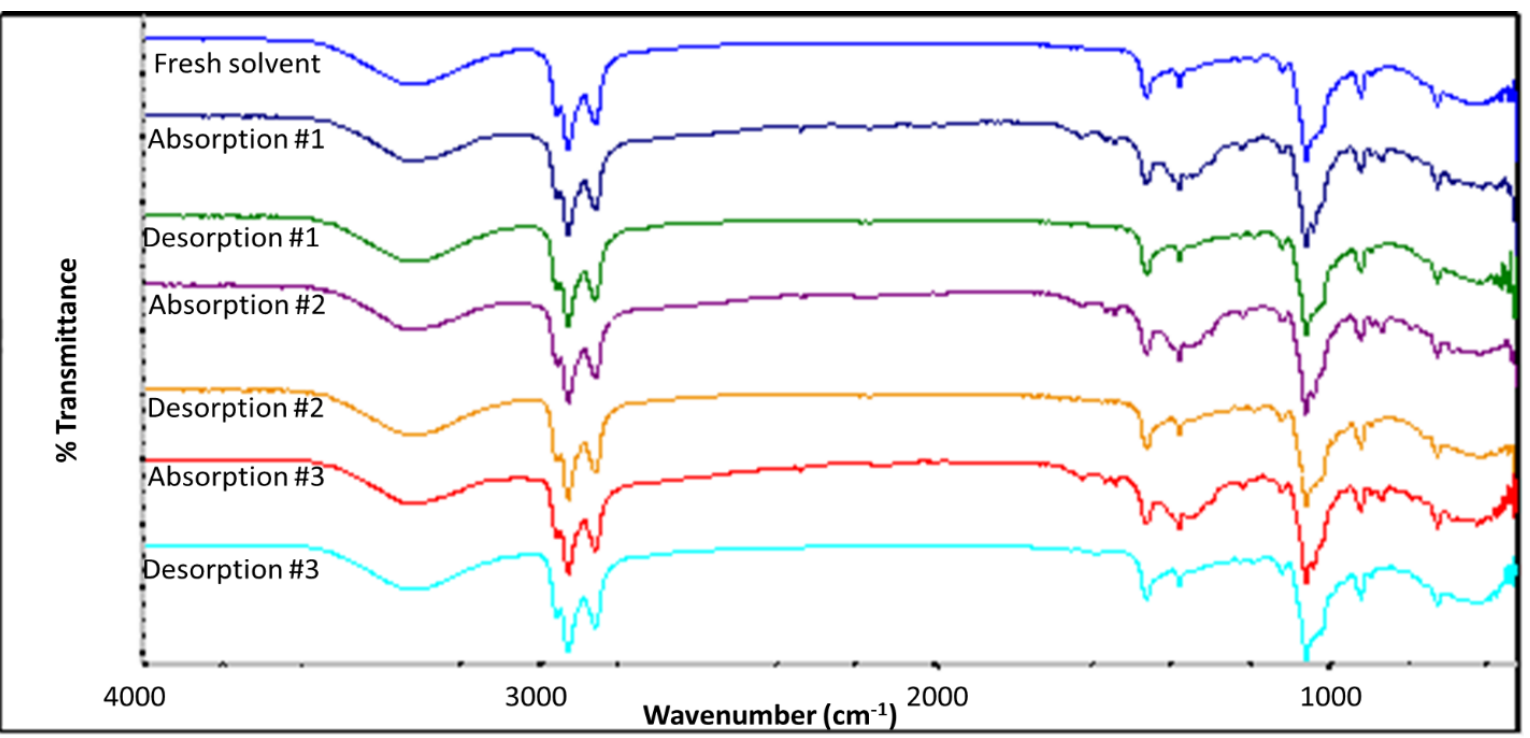

Figure 5. FTIR spectrum of AEPD: 1-hexanol system for 3 absorption-desorption cycles.

AEPD: 1-hexanol is capable of capturing 0.88 moles of $\mathrm{CO}_{2}$ per mole of AEPD and AEPD: 1-hexanol system catalyzed by $0.1 \mathrm{~g} / \mathrm{L}$ CA is capable of capturing 0.97 moles of $\mathrm{CO}_{2}$ per mole of AEPD (Figure 3). The $\mathrm{CO}_{2}$ absorption capacities for the AEPD: 1-hexanol systems are much higher than the theoretical value of $0.5 \mathrm{~mol} \mathrm{CO} / \mathrm{mol}$ MEA. [44]. As per the literature, the $\mathrm{CO}_{2}$ loading of tertiary amines is close to $0.9 \mathrm{~mol} \mathrm{CO} / \mathrm{mol}$ amine, except for MDEA [44]. The $\mathrm{CO}_{2}$ loading in aqueous MDEA allowed for the capture of $0.63 \mathrm{~mol} \mathrm{CO}_{2} / \mathrm{mol}$ MDEA, as reported by Jaafari et al., and $0.52 \mathrm{~mol} \mathrm{CO}_{2} / \mathrm{mol}$ MDEA, as reported by Hadri et al. $[6,29]$. The $\mathrm{CO}_{2}$ absorption capacity of AMP in ethane-1,2-diol was reported to be 0.71 by Im et al. [45]. These results indicate that the loading capacity of a non-aqueous solution of a sterically hindered primary amine (AEPD: 1-hexanol) was superior to that of the benchmark $\mathrm{CO}_{2}$ capturing agents. This in turn implies that if AEPD: 1-hexanol systems are employed, either in the presence or absence of CA, the solvent circulation rate of an absorber-desorber system will be accordingly decreased.

\section{Ultrasound-assisted desorption studies}

Ultrasound-assisted desorption studies were performed in a gas-liquid stirred cell contact reactor under 37 $\mathrm{kHz}$ ultrasonic irradiation. $\mathrm{CO}_{2}$ absorption was carried out at $303 \mathrm{~K}$ and 2 bar absolute pressure, desorption at $333 \mathrm{~K}$ and 1.1 bar absolute pressure, and ultrasound-assisted desorption at $333 \mathrm{~K}$ and 1.1 bar absolute pressure. The experiments on the AEPD: 1-hexanol systems were performed in the presence of $0.1 \mathrm{~g} / \mathrm{L} \mathrm{CA}$. The experimental results for the absorption and desorption performed under the abovementioned conditions showed that the $\mathrm{CO}_{2}$ loading and absorption time increase with an increase in the AEPD concentration for each solvent system (Figure 4).

From the above results, it can be concluded that ultrasound-assisted desorption of the $0.1 \mathrm{~g} / \mathrm{L} \mathrm{CA}$-catalyzed AEPD: 1-hexanol system is beneficial in terms of enhancement of both the $\mathrm{CO}_{2}$ desorption rate and the $\mathrm{CO}_{2}$ desorption capacity. It was observed that ultrasound irradiation significantly shortened the $\mathrm{CO}_{2}$ desorption time for biocatalytic $\mathrm{CO}_{2}$ capture by AEPD: 1-hexanol. Ultrasonic irradiation in the desorption process intensified bubble formation and decreased the gas-liquid mass transfer resistance, especially at the initial stage.

\section{FTIR analyses}

FTIR analyses were performed to study the regenerability and absorption-desorption performance losses of non-SHA solutions. A fresh AEPD:1-hexanol solvent, $\mathrm{CO}_{2}$-rich solvent after absorption at $303 \mathrm{~K}$ and 2 bar

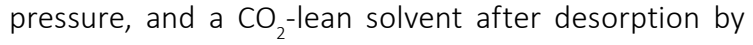
heat treatment at $363 \mathrm{~K}$ under $\mathrm{N}_{2}$ bubbling were examined for 3 absorption-desorption cycles. The FTIR spectra of the AEPD: 1-hexanol system are presented in Figure 5. 


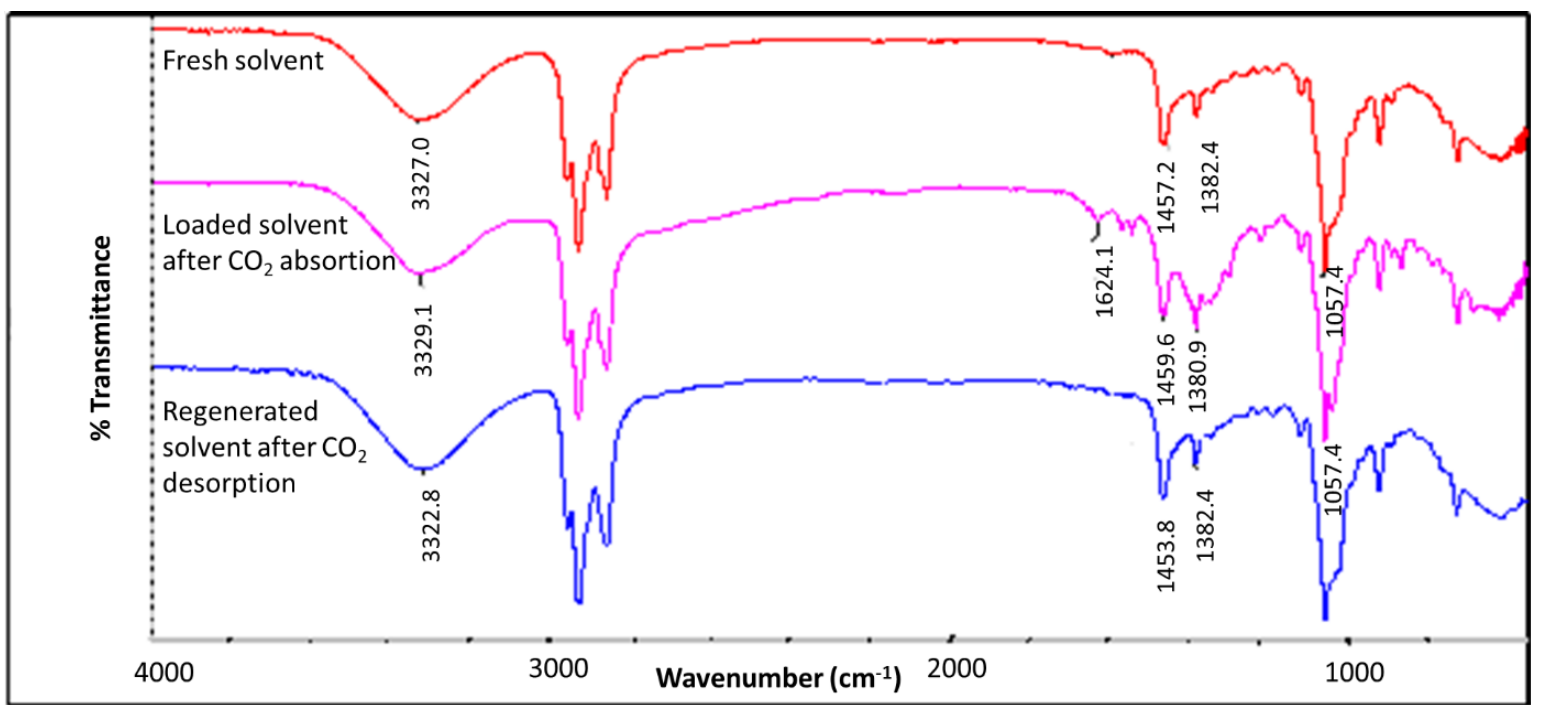

Figure 6. FTIR spectrum of AEPD: 1-hexanol system for the first absorption-desorption cycle.

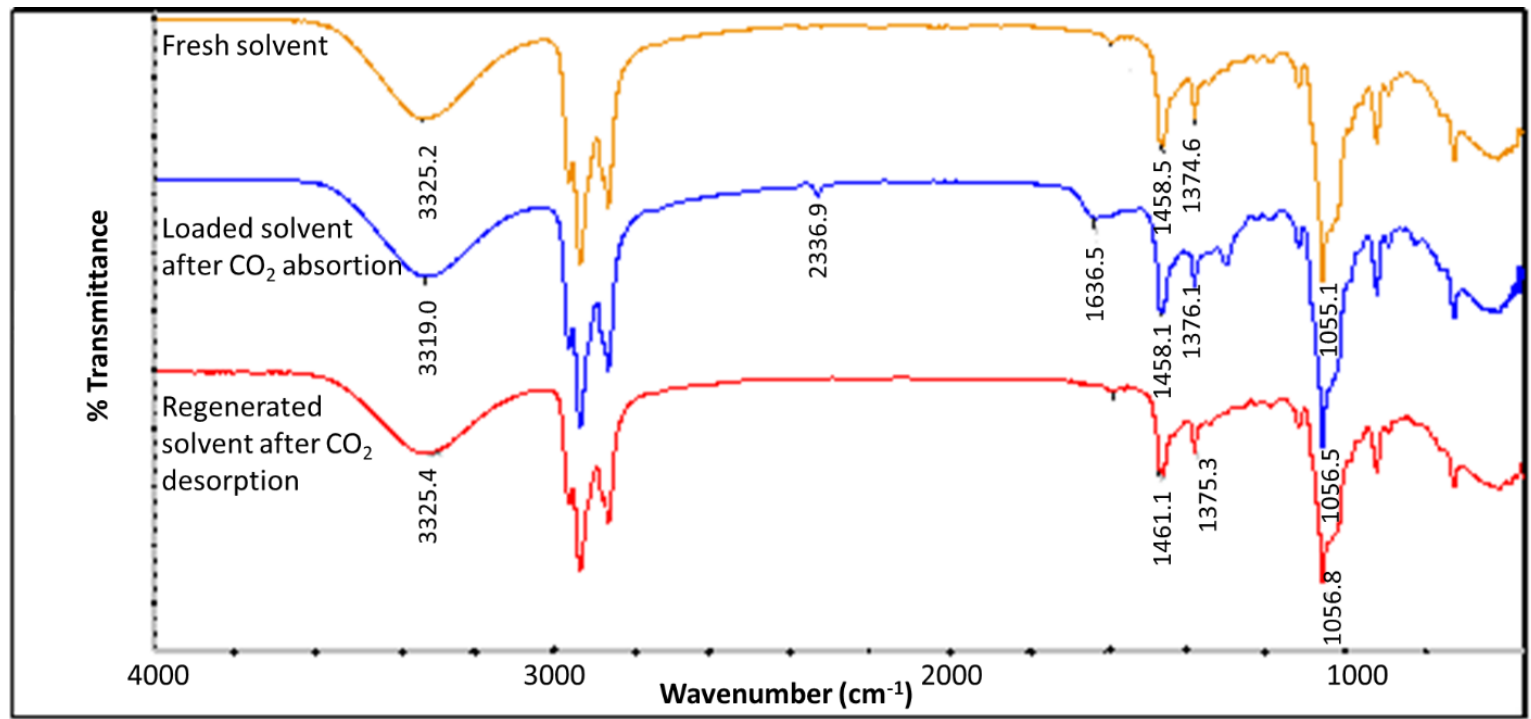

Figure 7. FTIR spectrum of AEPD: 1-hexanol system catalysed by $0.1 \mathrm{~g} / \mathrm{L} \mathrm{CA}$. 
In order to better understand the absorption-desorption performance of the AEPD:1-hexanol system, the FTIR spectrum of the fresh solvent, $\mathrm{CO}_{2}$-loaded solvent after the first absorption, and $\mathrm{CO}_{2}$-lean solvent after the first desorption were recorded (Figure 6). Fingerprint peaks for the $-\mathrm{OH}$ group were observed in the 3300$3400 \mathrm{~cm}^{-1}$ region, while AEPD showed a characteristic peak at $\sim 1050 \mathrm{~cm}^{-1}$. Peaks for the $\mathrm{C}=\mathrm{O}$ bond in the $\mathrm{CO}_{2}$ loaded solvent were observed between 1600 and 1650 $\mathrm{cm}^{-1}$. After desorption, the fingerprint peaks for the $\mathrm{C}=\mathrm{O}$ bond almost disappeared, and the spectrum of the lean solvent became similar to that of the fresh solvent.

The same procedure was repeated to observe the biocatalytic $\mathrm{CO}_{2}$ absorption-desorption performance of the AEPD: 1-hexanol solution in the presence of $0.1 \mathrm{~g} / \mathrm{L} \mathrm{CA}$. The FTIR spectra of the fresh solvent, loaded solvent after the first absorption at $303 \mathrm{~K}$ and 2 bar, and the lean solvent after the first desorption by heat treatment at $333 \mathrm{~K}$ under $\mathrm{N}_{2}$ bubbling are presented in Figure 7. The characteristic fingerprint peak of the CA enzyme was observed at $\sim 2330 \mathrm{~cm}^{-1}$. The results of the FTIR spectral analyses showed that the CA-activated non-SHA solution can be regenerated at $333 \mathrm{~K}$, which is far below the boiling point of 1-hexanol and other components of the solution, thus providing a significant advantage in preventing solvent loss by evaporation. This behavior could result in significant energy saving for post-combustion $\mathrm{CO}_{2}$ removal systems, where the traditional solvents require high energy in the form of latent heat.
Finally, ultrasound-assisted desorption was performed at $333 \mathrm{~K}$ under $\mathrm{N}_{2}$ bubbling to study the effect of ultrasound irradiation on the $\mathrm{CO}_{2}$ desorption performance. The FTIR spectra of the fresh AEPD: 1-hexanol system catalyzed by $0.1 \mathrm{~g} / \mathrm{L} \mathrm{CA}, \mathrm{CO}_{2}$-loaded solvent after absorption, and $\mathrm{CO}_{2}$-lean solvent after ultrasound-assisted desorption are shown in Figure 8.

After regeneration of the solution through ultrasoundassisted $\mathrm{CO}_{2}$ desorption, the loaded spectrum was converted to the lean solvent spectrum, which is almost identical to the spectrum of the fresh solvent.

\section{Conclusion}

In the present study, the cyclic absorption and desorption performance of different concentrations of an AEPD:1- hexanol system was studied in a stirred cell gas-liquid reactor. The biocatalytic effect of CA on the absorption capacity was also investigated. With the addition of $0.1 \mathrm{~g} / \mathrm{L} \mathrm{CA}$, the loading of 0.88 mole $\mathrm{CO}_{2} /$ mol AEPD was enhanced to $0.97 \mathrm{~mol} \mathrm{CO}_{2} / \mathrm{mol} A E P D$, which is much higher than the theoretical value of 0.5 mol $\mathrm{CO}_{2} / \mathrm{mol}$ MEA for MEA. The obtained results clearly show that the absorption capacity of the AEPD: 1-hexanol system can be enhanced by the addition of small amounts of $\mathrm{CA}$. Thus, $\mathrm{CO}_{2}$ capture using the proposed solvent system could be achieved with a lesser amount of reactant than that required for traditional amine systems. The AEPD: 1-hexanol system was recy-

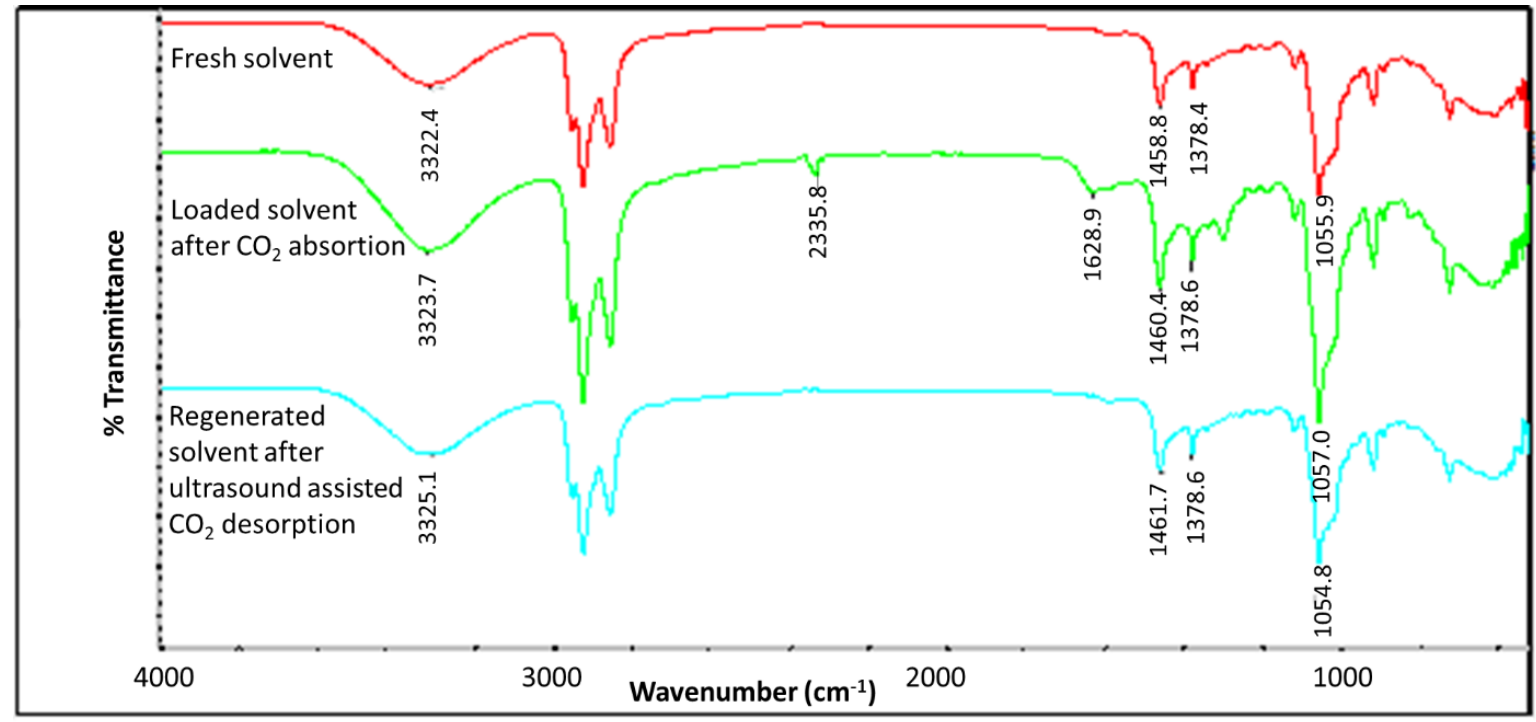

Figure 8. FTIR spectrum of AEPD: 1-hexanol system catalysed by $0.1 \mathrm{~g} / \mathrm{L} \mathrm{CA}$ (in the presence of ultrasound-assisted desorption). 
cled at least 3 times by desorption at $363 \mathrm{~K}$ and 1.1 bar absolute $\mathrm{N}_{2}$ pressure. The CA-catalyzed AEPD: 1-hexanol system was also recycled at least 3 times at $333 \mathrm{~K}$, without any considerable loss of capture capacity. These results indicate that this non-aqueous SHA system can be regenerated by simple heating, without boiling or any phase change. Thus, a conventional heavy-duty reboiler may not be required for regeneration. Further, the use of ultrasound-assisted desorption led to a significant increase in the desorption capacity and desorption rate, implying that this technique can minimize the energy consumption for regeneration. Finally, FTIR analyses confirmed the regeneration of the proposed solvent system at much lower temperatures than the boiling points of AEPD or 1-hexanol. To sum up, the AEPD: 1-hexanol solvent system, both in the presence and absence of CA, has potential application as a commercial solvent due to its high $\mathrm{CO}_{2}$ loading, low volatility, and less energy demand for regeneration by virtue of its non-aqueous nature.

\section{References}

1. R. Cassia, M. Nocioni, N. Correa-Aragunde, L. Lamattina, climate change and the impact of greenhouse gasses: $\mathrm{CO}_{2}$ and NO, friends and foes of plant oxidative stress, Front. Plant Sci., 9 (2018).

2. G.C.e.i. IEA (2020), IEA, Paris https://www.iea.org/articles/ global- $\mathrm{CO}_{2}$-emissions-in-2019.

3. T. Skytt, S.N. Nielsen, B.G. Jonsson, Global warming potential and absolute global temperature change potential from carbon dioxide and methane fluxes as indicators of regional sustainability - A case study of Jamtland, Sweden, Ecol. Indic., 110 (2020).

4. L.M. Romeo, M. Bailera, Design configurations to achieve an effective $\mathrm{CO} 2$ use and mitigation through power to gas, J. $\mathrm{CO}_{2}$ Util., 39 (2020).

5. J. Oexmann, A. Kather, Minimising the regeneration heat duty of post-combustion $\mathrm{CO}_{2}$ capture by wet chemical absorption: The misguided focus on low heat of absorption solvents, Int. J. Greenh. Gas. Con., 4 (2010) 36-43.

6. N.E.L. Hadri, D.V. Quang, M.R.M. Abu-Zahra, Study of novel solvent for $\mathrm{CO}_{2}$ post-combustion capture, Enrgy. Proced., 75 (2015) 2268-2286.

7. J.Y. Yang, W. Yu, T. Wang, Z.Z. Liu, M.X. Fang, Process Simulations of the Direct Non-Aqueous Gas Stripping Process for $\mathrm{CO}_{2}$ Desorption, Ind. Eng. Chem. Res., 59 (2020) 7121-7129.

8. B. Aghel, S. Sahraie, E. Heidaryan, Comparison of aqueous and non-aqueous alkanolamines solutions for carbon dioxide desorption in a microreactor, Energy, 201 (2020).

9. X.Y. Zhu, H.F. Lu, K.J. Wu, Y.M. Zhu, Y.Y. Liu, C.J. Liu, B. Liang, DBU-Glycerol Solution: $\mathrm{A} \mathrm{CO}_{2}$ Absorbent with high desorption ratio and low regeneration energy, Environ. Sci. Technol., 54 (2020) 7570-7578.
10. M.C. Ozturk, O.Y. Orhan, E. Alper, Kinetics of carbon dioxide binding by 1,1,3,3-tetramethylguanidine in 1-hexanol, Int. J. Greenh. Gas Con., 26 (2014) 76-82.

11. O.Y. Orhan, H. Tankal, H. Kayi, E. Alper, Kinetics of $\mathrm{CO}_{2}$ capture by carbon dioxide binding organic liquids: Experimental and molecular modelling studies, Int. J. Greenh. Gas. Con., 49 (2016) 379-386.

12. M. Ozkutlu, O.Y. Orhan, H.Y. Ersan, E. Alper, Kinetics of $\mathrm{CO}_{2}$ capture by ionic liquid- $\mathrm{CO}_{2}$ binding organic liquid dual systems, Chem. Eng. Process., 101 (2016) 50-55.

13. O.Y. Orhan, C.S. Ume, E. Alper, The absorption kinetics of $\mathrm{CO}_{2}$ into ionic liquid- $\mathrm{CO}_{2}$ binding organic liquid and hybrid solvents, Green. Energy. Technol., (2017) 241-261.

14. B.H. Lv, K.X. Yang, X.B. Zhou, Z.M. Zhou, G.H. Jing, 2-Amino2-methyl-1-propanol based non-aqueous absorbent for energy-efficient and non-corrosive carbon dioxide capture, Appl. Energ., 264 (2020).

15. F. Bougie, D. Pokras, X.F. Fan, Novel non-aqueous MEA solutions for $\mathrm{CO}_{2}$ capture, Int. J. Greenh. Gas Con., 86 (2019) 34-42.

16. C.X. Li, X.Q. Shi, S.F. Shen, Performance evaluation of newly developed absorbents for solvent-based carbon dioxide Capture. Energy \& Fuels, 33 (2019) 9032-9039.

17. P.V. Kortunov, M. Siskin, M. Paccagnini, H. Thomann, CO2 Reaction mechanisms with hindered alkanolamines: control and promotion of reaction pathways, Energ. Fuel., 30 (2016) 1223-1236.

18. W. Conway, S. Bruggink, Y. Beyad, W.L. Luo, I. MelianCabrera, G. Puxty, P. Feron, $\mathrm{CO}_{2}$ absorption into aqueous amine blended solutions containing monoethanolamine (MEA), N,N-dimethylethanolamine (DMEA), N,Ndiethylethanolamine (DEEA) and 2-amino-2-methyl-1propanol (AMP) for post-combustion capture processes, Chem. Eng. Sci. 126 (2015) 446-454.

19. S. Camino, F. Vega, L.M.G. Fernandez, M. Cano, J.A. Camino, B. Navarrete, Kinetic evaluation of sterically hindered amines under partial oxy-combustion conditions, J. Chem. Technol. Biotechnol., (2020).

20. F. Bougie, M.C. Iliuta, Sterically Hindered Amine-Based Absorbents for the Removal of $\mathrm{CO}_{2}$ from Gas Streams. J. Chem. Eng. Data, 57 (2012) 635-669.

21. S.J. Yoon, H. Lee, J.H. Yoon, J.G. Shim, J.K. Lee, B.Y. Min, H.M. Eum, Kinetics of absorption of carbon dioxide into aqueous 2-amino-2-ethyl-1,3-propanediol solutions, Ind. Eng. Chem. Res., 41 (2002) 3651-3656.

22. M.P. Patil, P.D. Vaidya, Aqueous mixtures of AMP, HMDA-N,N '-dimethyl and TEG for $\mathrm{CO}_{2}$ separation: a study on equilibrium and reaction kinetics, Chem. Eng. Commun., (2019).

23. N. Prasongthum, P. Natewong, P. Reubroycharoen, R. Idem, Solvent regeneration of a $\mathrm{CO}_{2}$-loaded BEA-AMP Bi-blend amine solvent with the aid of a solid bronsted $\mathrm{Ce}(\mathrm{SO} 4)(2) /$ $\mathrm{ZrO}_{2}$ superacid catalyst, Energ. Fuel., 33 (2019) 1334-1343.

24. M.P. Patil, P.D. Vaidya, Kinetics of $\mathrm{CO}_{2}$ Absorption into Aqueous AMP/HMDA/TEG Mixtures, Chemistryselect, 3 (2018) 195-200.

25. S.K. Dash, A.N. Samanta, S.S. Bandyopadhyay, Simulation and parametric study of post combustion $\mathrm{CO}_{2}$ capture process using (AMP plus PZ) blended solvent, Int. J. Greenh. Gas Con., 21 (2014) 130-139.

26. A.K. Saha, S.S. Bandyopadhyay, A.K. Biswas, Kinetics of absorption of $\mathrm{CO}_{2}$ into aqueous-solutions of 2-amino-2methyl-1-oropanol, Chem. Eng. Scie., 50 (1995) 3587-3598. 
27. S. Kumar, M.K. Mondal, Selection of efficient absorbent for $\mathrm{CO}_{2}$ capture from gases containing low $\mathrm{CO}_{2}$, Korean J. Chem. Eng., 37 (2020) 231-239.

28. S. Ullah, H. Suleman, M.S. Tahir, M. Sagir, S. Muhammad, A.G. Al-Sehemi, M.U.R. Zafar, F.A.A. Kareem, A.S. Maulud, M.A Bustam, Reactive kinetics of carbon dioxide loaded aqueous blend of 2-amino-2-ethyl-1,3-propanediol and piperazine using a pressure drop method, Int. J. Chem. Kinet., 51 (2019) 291-298.

29. L. Jaafari, B. Jaffary, R. Idem, Screening study for selecting new activators for activating MDEA for natural gas sweetening, Sep. Purif. Technol., 199 (2018) 320-330.

30. O.Y. Orhan, E. Alper, Kinetics of carbon dioxide binding by promoted organic liquids, Chem. Eng. Technol., 38 (2015) 1485-1489.

31. T. Sharma, S. Sharma, H. Kamyab, A. Kumar, Energizing the $\mathrm{CO}_{2}$ utilization by chemo-enzymatic approaches and potentiality of carbonic anhydrases: A review, J. Clean. Prod., 247 (2020).

32. N. Cihan, O.Y. Orhan, The enhanced enzymatic performance of carbonic anhydrase on the reaction rate between $\mathrm{CO}_{2}$ and aqueous solutions of sterically hindered amines, Greenh. Gases, (2020).

33. B. Liu, X. Luo, Z.W. Liang, W. Olson, H.L. Liu, R. Idem, P. Tontiwachwuthikul, The development of kinetics model for $\mathrm{CO}_{2}$ absorption into tertiary amines containing carbonic anhydrase, Aiche J., 63 (2017) 4933-4943.

34. Y.Z. Wang, M.F. Li, Z.P. Zhao, W.F. Liu, Effect of carbonic anhydrase on enzymatic conversion of $\mathrm{CO}_{2}$ to formic acid and optimization of reaction conditions, J. Mol. Catal. B-Enzym., 116 (2015) 89-94

35. I. Iliuta, M.C. Iliuta, F. Larachi, Catalytic $\mathrm{CO}_{2}$ hydration by immobilized and free human carbonic anhydrase II in a laminar flow microreactor - Model and simulations, Sep. Purif. Technol., 107 (2013) 61-69.
36. P. Mirjafari, K. Asghari, N. Mahinpey, Investigating the application of enzyme carbonic anhydrase for $\mathrm{CO}_{2}$ sequestration purposes, Ind. Eng. Chem. Res., 46 (2007) 921-926.

37. J.R. Ying, D.A. Eimer, A. Mathisen, F. Brakstad, H.A. Haugen, Ultrasound intensify $\mathrm{CO}_{2}$ desorption from pressurized loaded monoethanolamine solutions. II. Optimization and cost estimation, Energy, 173 (2019) 218-228.

38. X.K. Xing, C.B. Feng, Enhancing $\mathrm{CO}_{2}$ desorption from crude oil by ultrasound, Ultrasonics, 84 (2018) 74-80.

39. O. Yuksel Orhan, Keles, Y., Yavuz Ersan, H., Alper, E., Ultrasound-assisted desorption of $\mathrm{CO}_{2}$ from carbon dioxide binding organic liquids, Energy Procedia 114 (2017) 66-71.

40. K. Tanaka, H. Okawa, T. Fujiwara, T. Kato, K. Sugawara, Desorption of $\mathrm{CO}_{2}$ from low concentration monoethanolamine solutions using calcium chloride and ultrasound irradiation, Jpn. J. Appl. Phys., 54 (2015).

41. P.V. Danckwerts, Reaction of $\mathrm{CO}_{2}$ with Ethanolamines, Chem. Eng. Sci., 34 (1979) 443-446.

42. O.Y. Orhan, E. Alper, Kinetics of reaction between $\mathrm{CO}_{2}$ and ionic liquid-carbon dioxide binding organic liquid hybrid systems: Analysis of gas-liquid absorption and stopped flow experiments, Chem. Eng. Sci., 170 (2017) 36-47.

43. O.Y. Orhan, M.C. Ozturk, A. Seker, E. Alper, Kinetics and performance studies of a switchable solvent TMG (1,1,3,3-tetramethylguanidine)/1-propanol/carbon dioxide system, Turk. J. Chem., 39 (2015) 13-24.

44. H.X. Gao, Z.Y. Wu, H. Liu, X. Luo, Z.W. Liang, Experimental studies on the effect of tertiary amine promoters in aqueous monoethanolamine (MEA) solutions on the absorption/ stripping performances in post-combustion $\mathrm{CO}_{2}$ capture, Energ. Fuel., 31 (2017) 13883-13891.

45. J. Im, S.Y. Hong, Y. Cheon, J. Lee, J.S. Lee, H.S. Kim, M. Cheong, $\mathrm{H}$. Park, Steric hindrance-induced zwitterionic carbonates from alkanolamines and $\mathrm{CO}_{2}$ : highly efficient $\mathrm{CO}_{2}$ absorbents, Energy Environ. Sci., 4 (2011) 4284-4289. 